\title{
New Labour and the new world order
}

Britain's role in the war on terror

Steven Kettell 


\section{New Labour and the new world order}

\section{MANCHESTER 1824}

Manchester University Press 
For Zach

Steven Kettell - 9781847794581 


\title{
New Labour and the new world order
}

\section{Britain's role in the war on terror}

\author{
Steven Kettell
}

Manchester University Press

Manchester and New York

distributed in the United States exclusively

by Palgrave Macmillan 


\section{Copyright @ Steven Kettell 2011}

The right of Steven Kettell to be identified as the author of this work has been asserted by him in accordance with the Copyright, Designs and Patents Act 1988.

Published by Manchester University Press

Oxford Road, Manchester M13 9NR, UK

and Room 400, 175 Fifth Avenue, New York, NY 10010, USA

www.manchesteruniversitypress.co.uk

Distributed in the United States exclusively by

Palgrave Macmillan, 175 Fifth Avenue, New York,

NY 10010, USA

Distributed in Canada exclusively by

UBC Press, University of British Columbia, 2029 West Mall,

Vancouver, BC, Canada V6T 1Z2

British Library Cataloguing-in-Publication Data

A catalogue record for this book is available from the British Library

Library of Congress Cataloging-in-Publication Data applied for

ISBN 9780719081361 hardback

First published 2011

The publisher has no responsibility for the persistence or accuracy of URLs for any external or third-party internet websites referred to in this book, and does not guarantee that any content on such websites is, or will remain, accurate or appropriate.

Typeset

by Frances Hackeson Freelance Publishing Services, Brinscall, Lancs

Printed in Great Britain

by CPI Antony Rowe Ltd, Chippenham, Wiltshire 